\title{
Prototype Expert System Application to Identify Specific Children Learning Disabilities in Inclusion Schools
}

\author{
Supriyadi Supriyadi ${ }^{1 *}$, Dian Atnantomi Wiliyanto ${ }^{1}$, \\ ${ }^{1}$ Sebelas Maret University, Surakarta, Indonesia
}

\begin{abstract}
This study aims to develop an expert system application for the identification of specific children learning disabilities in Inclusion School. The research method used is development research design ( $R$ \& $D$ ) to test the effectiveness of the use of identification of specific children learning disabilities with expert system application. Application testing involving 40 teachers in inclusion schools to test expert system applications in identification. Validate results by teachers in inclusion schools obtained that from aspects of system display, user, accuracy, and system responsibility have an average of 4.20 fall into the category of excellent. Expert system application development has several features, among others; home menu, analysis, and intervention to follow up learning services, learning media, and classroom embedding for specific children learning disabilities.
\end{abstract}

Keywords: Expert system, learning disabilities, inclusion schools

\section{Research Background}

Inclusion Education is an education system that provides space for Children with Special Needs to be able to attend school with regular learners in one class. Schools that implement inclusion education provide special services and attention to Children with special needs to be able to process education regularly (Agustin, 2019).

Children with Special Needs have different characteristics - different from various uniqueness (Hallahan \& Kauffman, 2006; Rapisa, 2018). The characteristics of children with diverse special needs cause teachers to become more likely to identify (Rapisa, 2018). Master's understanding of poor identification leads to errors in providing learning services to Children with Special Needs. This causes the lag of Children with Special Needs with other regular learners.

Specific children learning disabilities become the most difficult to identify because by birth it is not visible (Raharjo, et al, 2011). Learning disabilities have small differences in physical and mental aspects compared to regular children, thus causing difficulty in carrying out proper identification (Cavendish, 2013; Russell et al., 2017). This problem is becoming increasingly crucial in inclusion schools, where analysis of teacher identification understanding in inclusion schools shows that under-understanding 
teachers are $37 \%$, incomprehensible (23\%), and lack of understanding (18\%) (Wiliyanto, 2017a). This is influenced by most of the teachers not from Outstanding Education graduates. This is based on data from Special Assistance Teachers in Surakarta, 65\% of teachers are not graduates of Special Education Education and 35\% of Special Education graduates (Wiliyanto, 2017a).

With resources in schools that cause problems in identifying, especially in children with specific learning disabilities whose symptoms or characteristics are very difficult to detect. Late identification of children with learning disabilities will lead to child lags in cognitive and social development (Mensah \& Badu-Shayar, 2016). This causes the inclusion school work program needs improvement or cooperation with various parties so that education services by the needs of children according to the identification results (Mapunda et al., 2017).

The era of industry 4.0 has an impact on digitization in various fields, including the development of applications for identification (Cheng \& Lai, 2020). During the covid 19 pandemics, digital-based identification is increasingly needed. Moreover, factors to make it easier for teachers who have difficulty in identifying specific children learning disabilities are required identification applications that are easily accessible to all teachers (Wiliyanto, 2017b). The use of expert system application provides an algorithm to solve problems based on symptoms or characteristics that appear so that it can be concluded a problem that wants to be detected (Al Hakim et al., 2020; Wiliyanto, 2017b).

The advantages of the expert system can be used as the basis for its use in the identification of specific children learning disabilities that have characteristics that are difficult to detect so that applications are needed that can give decisions in a structured and based on the symptoms that appear. This provides accuracy in child identification including learning disabilities or not, which will be a reference for learning programs, learning media, and placement of children following the identification results of the expert system application (Wiliyanto, 2017b).

\section{Research Methodology}

\subsection{1 Study design}

This research is using a development research design (R \& D). The stages of development are divided into three stages, namely, the stage of (1) needs analysis, (2) design, and (3) testing. At the stage of needs, analysis was carried out a needs survey on identification. To determine whether children experience learning disabilities or not in the developed system has adopted the decision tree as the determinant. The decision tree in the system is based on symptoms or signs that appear when a child is observed as determinants including learning disabilities or not. To see how the system works in conducting identification briefly can be seen in figure 1, the following: 


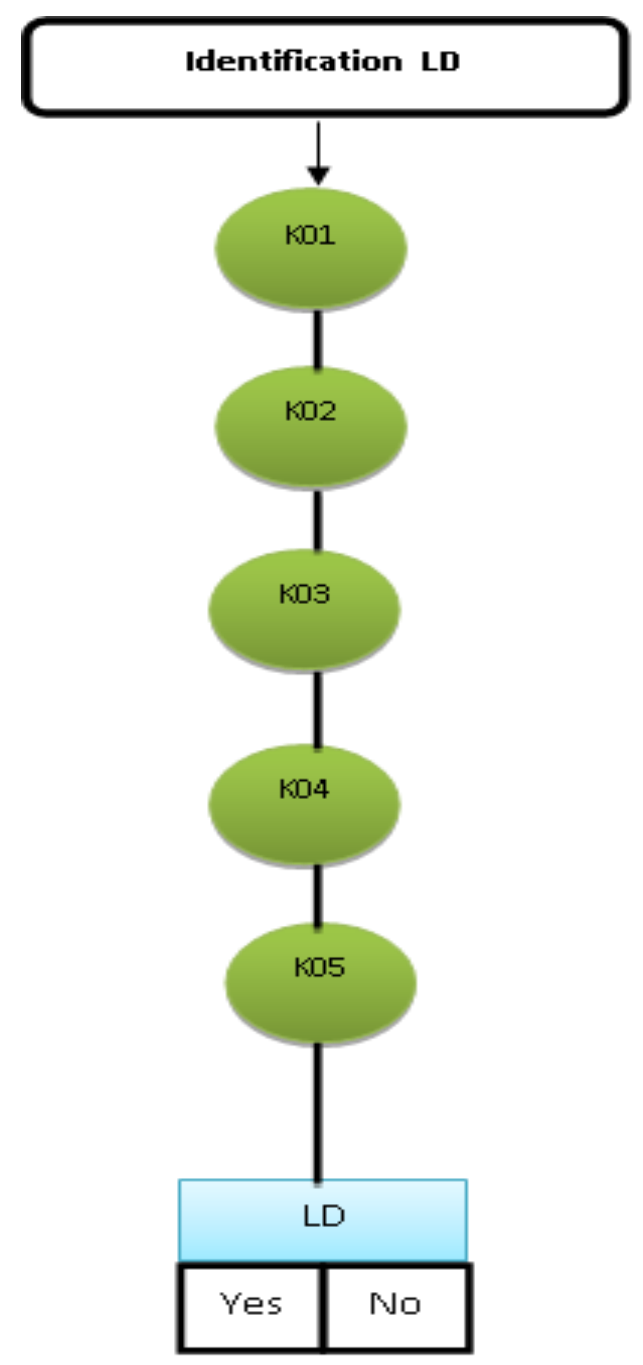

Picture 1. Expert System Application Decision Tree

\subsection{Participant}

The validation of prospective users is done after the initial product revision where the product deficiency has been corrected based on revisions from experts and limited field tests. The user candidate test was conducted in 11 inclusive schools in Surakarta that are members of the inclusive KKG of Surakarta City with a total of 40 special assistance teachers, inclusion coordinators, principals, and classroom teachers. Researchers will share questionnaires about the appearance of expert systems and manuals on the use of expert system applications. The study subjects were asked to provide a note or description for final product revision and form the final product of the expert system application.

\subsection{Instrument}

Instruments used to test the feasibility of prototype expert system applications by users in the field. Researchers develop instruments with items - items that are used to 
know the identification system can run well in identifying children with a learning disability, the following instruments are:

\begin{tabular}{|l|l|}
\hline NO & \multicolumn{2}{|l|}{ ITEM } \\
\hline SYSTEM \\
\hline 1 & Expert system application display is easy to clear and understand \\
\hline 2 & The expert system application is easy to operate \\
\hline 3 & Expert system application has quality resolution / graphical sharpness/layout \\
\hline USER & \\
\hline 4 & Expert system application menu display is easy to understand \\
\hline 5 & Image symbols are easy to understand \\
\hline 6 & There is an easy-to-download edit, save and print menu \\
\hline RELIABILITY \\
\hline 7 & $\begin{array}{l}\text { The expert system application can process data processing (save, edit, delete, } \\
\text { and view data) appropriately }\end{array}$ \\
\hline 8 & $\begin{array}{l}\text { The expert system application can run if there is an error both in the login } \\
\text { process and data processing (save, edit, delete, and view data) }\end{array}$ \\
\hline INTEGRITY \\
\hline 9 & Expert system application can give a clear message when something happens \\
\hline 10 & $\begin{array}{l}\text { Expert system application can control user access by limiting access rights } \\
\text { through admin }\end{array}$ \\
\hline INTERACTION \\
\hline 11 & Expert system application can be operated or used easily \\
\hline 12 & Expert system application has a well-guaranteed security system \\
\hline
\end{tabular}

\subsection{Data collection}

Expert validation using qualitative and quantifiable analysis techniques. Validation is done by a predetermined expert to know the feasibility of expert system application and manual. Data assessment of the feasibility of expert system application development products with scale rating. Data can be qualitative data containing comments about products developed Determination of validity and revision of products, according to Sugiyono (2017:50) states the category of validation can be seen based on the interpretation table as follows:

Table 1. Feasibility criteria

\begin{tabular}{|l|l|}
\hline Criteria & Score \\
\hline Very good & $4.00-5.00$ \\
\hline Good & $3.00-3.99$ \\
\hline Not good enough & $2.00-2.99$ \\
\hline Not good & $1.00-1.99$ \\
\hline
\end{tabular}

The test involves teachers in an inclusion school of 40 teachers as validators to test the feasibility of expert system applications. The data obtained is processed using 
SPSS and then the results obtained are described by the researchers to explain the results.

\section{Results}

The results of the study conducted by testing expert system application for identification of children-specific learning disabilities with teacher validators in inclusive schools obtained the following results:

Table 2. Feasibility of expert system application

\begin{tabular}{ll}
\hline Assessment Aspects & Scores \\
\hline System view & 5 \\
User & 4.20 \\
Accuracy & 3.75 \\
Responsibility system & 4 \\
Average & 4.20 \\
& (Very good) \\
\hline
\end{tabular}

Table 2 shows validate results by teachers in inclusion schools obtained that from aspects of system display, user, accuracy, and system responsibility have an average of 4.20 fall into the category of very good.

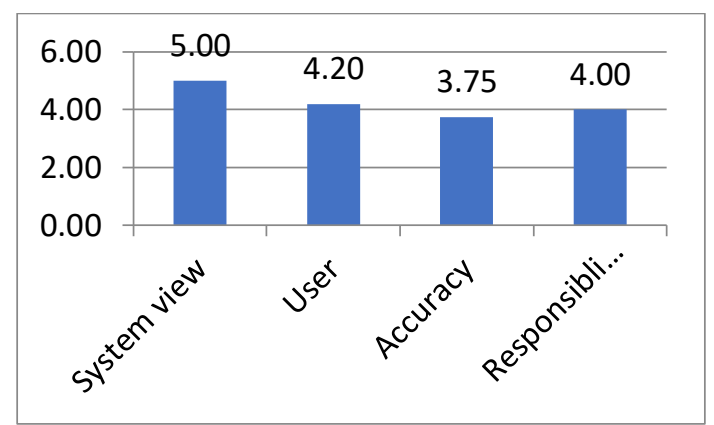

Picture 2. Expert system application feasibility diagram

Expert system application display developed based on the needs in the field by the analysis of the needs obtained application display that has three main menus, namely;

\subsection{Home}

This menu displays the face of the expert system application which contains how the application works and information about children learning disabilities through video, such as the following: 


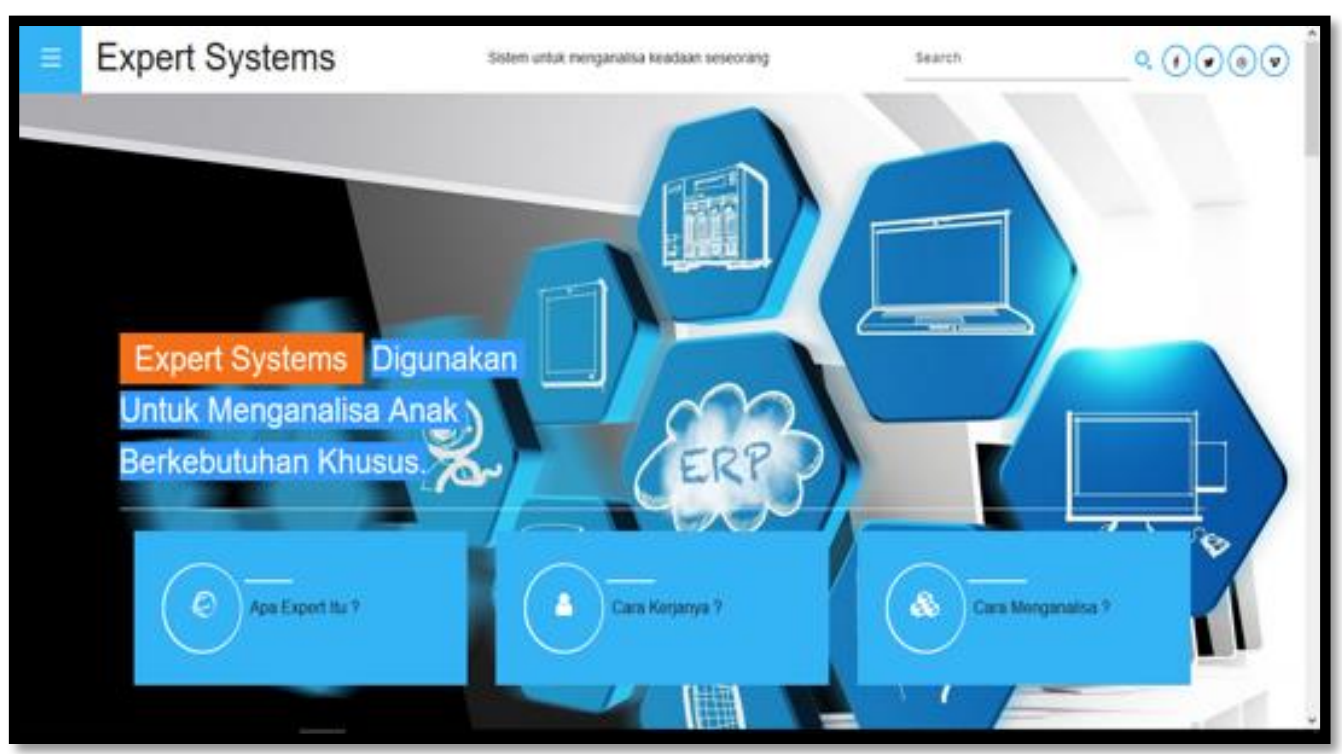

Picture 3. Home

\subsection{Analysis of Menu}

This menu is the main menu used to identify children with specific learning disabilities. This display contains symptoms or characteristics that appear in children who are suspected of learning disabilities.

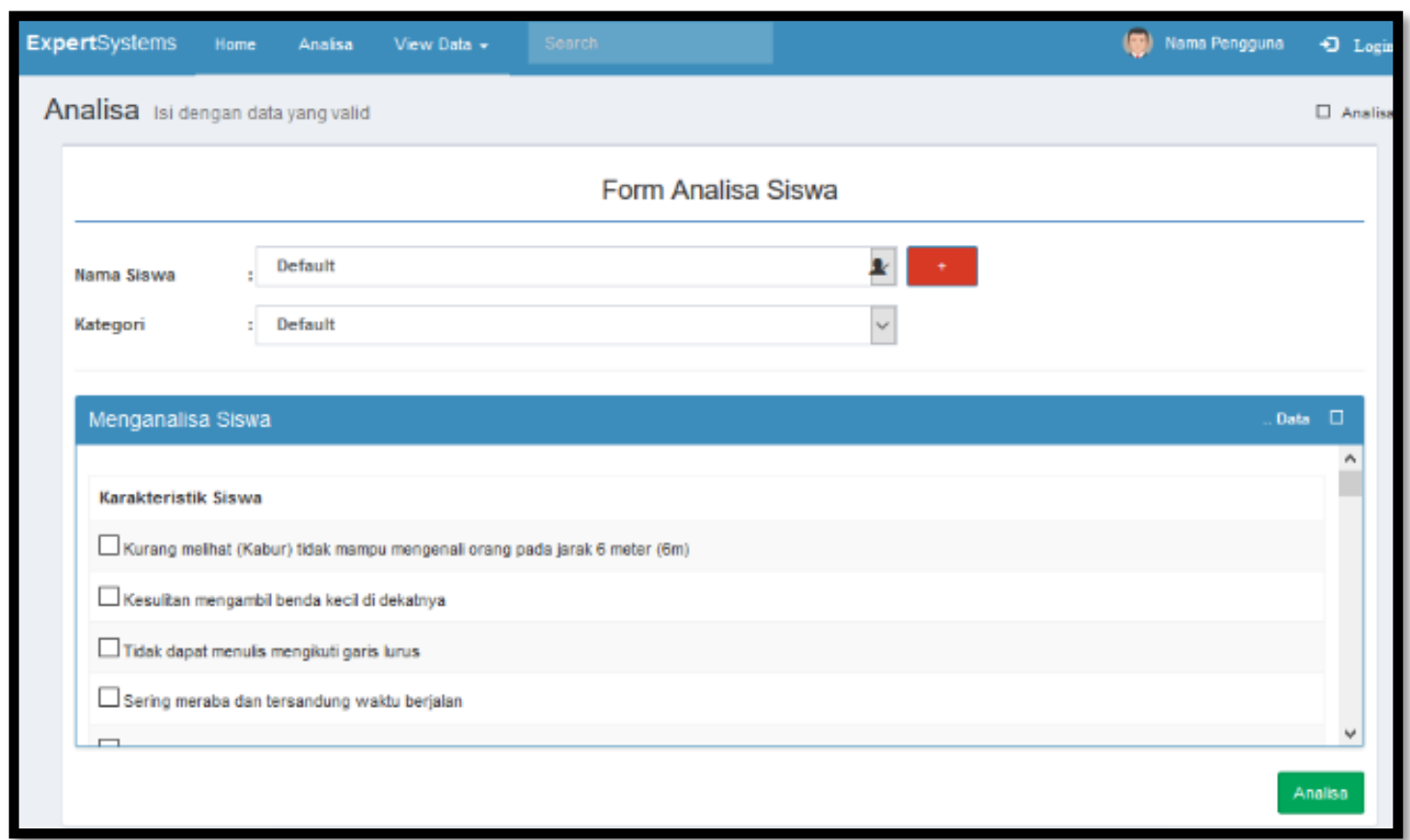

Picture 4. Analysis menu

\subsection{Intervention Menu}

This intervention menu is the result of an analysis that has been done on the previous menu. This menu described learning services, media defense, and class placement for specific children learning disabilities by the identification results. 


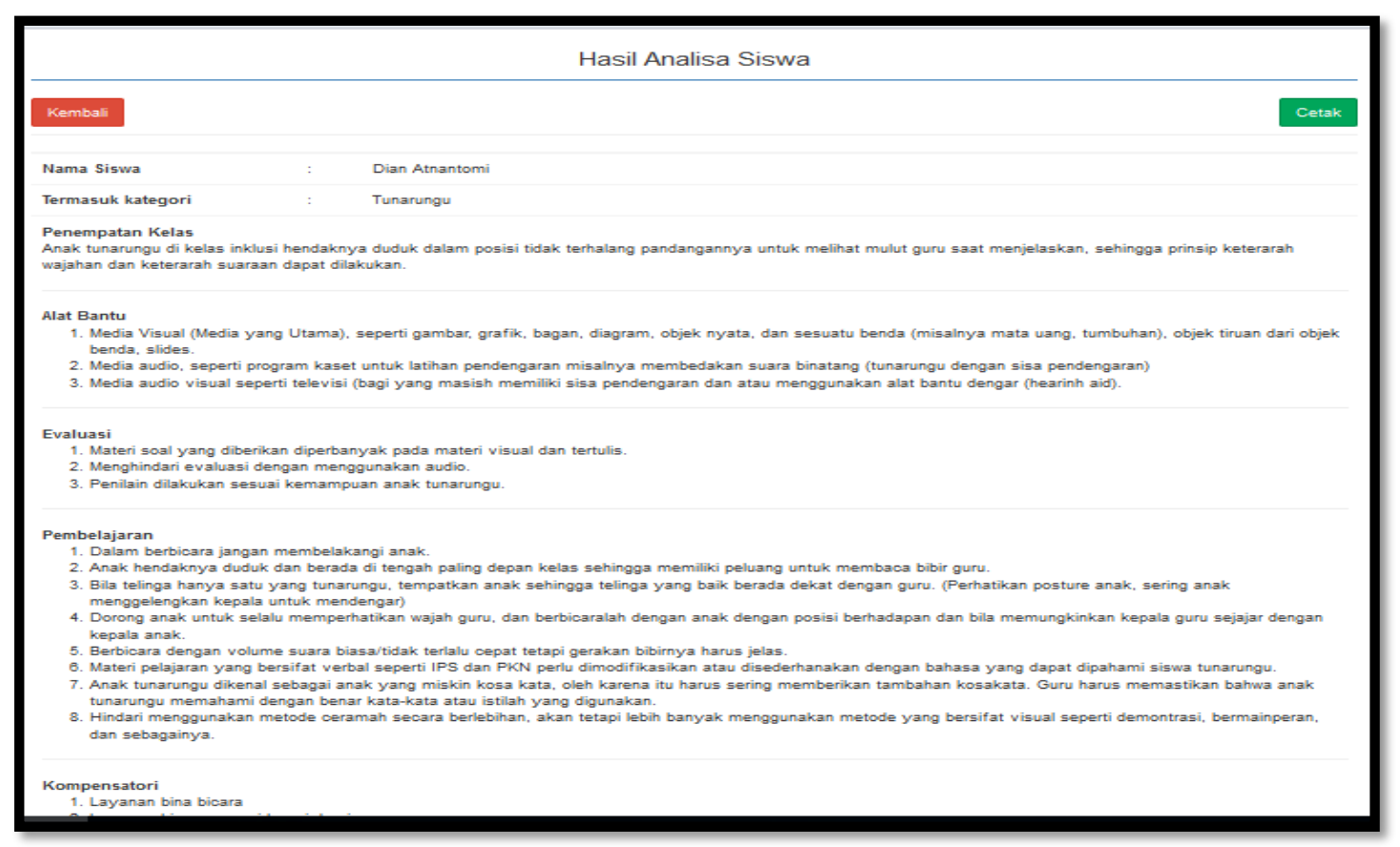

Picture 5. Intervention Menu

\section{Discussion}

Validation results are done with an average of 4.20 with excellent criteria. The use of an expert system or expert system can be used by teachers to determine the right identification and intervention for children with special needs. In the study using the help of a decision support system application can be used to identify motor disorders (Rejeki, 2019). An expert system is a computer-based system that uses knowledge, facts, and reasoning techniques in solving problems that can usually only be solved by expert systems in certain fields that can give a decision about a problem experienced (Al Hakim et al., 2020). The advantages of using expert systems or expert systems in the world of education, among others, to solve learning problems of learners, to provide interventions that are by the problems experienced by learners (Goodarzi \& Rafe, 2012). Determination of identification and level of intelligence and interests and classes by the ability of learners can be done by expert systems or expert systems sourced from databases (Nugraha \& Herlawati, 2016).

Expert system to help the development of education and help students and teachers in learning in the classroom (Sora, J.C.; Sora, 2014). In-class learning the expert system can play a role in solving learning problems that are considered difficult such as mathematics and science for students in the school (Salekhova et al., 2013). In education children with special needs, a web-based expert system is used to facilitate deaf children in accessing learning in the classroom (Elgaml \& Baladoh, 2014).

Class determination for newly entered learners can be done with an expert system application, where the system provides class recommendations and learning plans suitable for learners by their intellectual condition (Al-Ghamdi et., 2012; Bouaiachi et al., 2014). Another research expert system is a system that can be used to provide 
recommendations on academic plans about learning options that are by the conditions of learners (Ayman, 2011). Expert systems can provide an overview of the interests and IQ of learners. Characteristics of learners identified, an expert system for training recommendations by the educational history stored in the database that is useful in overcoming learning problems experienced by learners (Daramola et al., 2014). The use of web-based applications determines recommendations for lesson schedule decisions and the level of completeness and provides training or intervention recommendations that are by the intellectual condition of the learner. Curriculum determination that suits the condition of learners can use web-based applications that provide accurate decisions (Lightfoot, 2014). The assessment process or assessment of web-based expert systems can play a role in evaluating the learning outcomes of learners who have been developed or planned.

The use of expert system application can be used as a diagnosis of learners' learning problems such as writing, reading, counting, and socialization problems (Hustinawaty \& Aprianggi, 2014). Decisions resulting from the analysis of expert system applications are adjusted to the real circumstances based on the condition of the learners and provide an overview of behavior and cognition (Alfiah et al., 2019). The equation of using the expert system application for teachers in schools is to know the problems experienced by students and determine the right services according to their needs.

Characteristics of students identified, an expert system for training recommendations following the educational history stored in the database that is useful in addressing learning problems experienced by students (Daramola et al,2014). The use of web-based applications determines the recommendations of lesson schedule decisions and completion levels and provides recommendations for exercises or interventions that are appropriate to the intellectual condition of learners (Albalooshi \& Shatnawi, 2010). Determination of curriculum following the conditions of learners can use web-based applications that provide accurate decisions (Lightfoot, 2014; Susanti,2015). The process of assessment or assessment of web-based expert systems can play a role in evaluating the learning outcomes of students who have been developed or planned before (Choudhury et al,2012,2013; Muntoha et al,2010). Webbased applications provide data archives that can be used to determine the criteria for assessment standards and interventions that suit the conditions of learners (Yorulmaz, 2012).

The use of an expert system or expert system is one that teachers can use to determine the right identification and intervention for children with special needs. In line with Salim's research, Subagya, Yusuf, and Sari (2015) using the help of decision support system application can be used to identify children with autism. An expert system is a computer-based system that uses knowledge, facts, and reasoning 
techniques in solving problems that can usually only be solved by expert systems in a particular field that can give a decision about a problem experienced (Ignizio, 1991).

Decisions resulting from the analysis of expert system applications are adjusted to the actual circumstances based on the condition of the learners. The similarity of the use of expert system applications for teachers in schools is to know the problems experienced by students and determine the services that are in line with the needs.The difference from the research developed with the use of expert system application is used to identify specific children learning disabilities that explain the barriers (categories) of children with special needs and provide recommendations for handling by the needs of learners. Recommendations for handling according to the analysis of children with special needs include class placement, learning media, and evaluation.

\section{Conclusion}

Expert judgment's validation conducted in the development of this expert system application shows the feasibility and can be used in the field. The results of the development resulted in the appearance of the application menu consisting of three main menus, namely; home menu, analysis, and intervention. The application provides convenience to teachers in inclusion schools to determine learning services, learning media, and placements that are by the abilities and needs of specific children learning disabilities that are identified with the expert system application.

\section{References}

Albalooshi, Fawzi \& Shatnawi, Safwan. (2010), "HE-Advisor: a multidisciplinary webbased higher education advisory system", Global Journal of Computer Science and Technology, Vol. 10, No. 7, Page $37-49$.

Agustin, I. (2019), "Penerapan identifikasi, asesmen dan pembelajaran bagi Anak berkebutuhan khusus di sekolah dasar Penyelenggara pendidikan inklusi", Jurnal Pendidikan Dasar, Vol. 3, No 2, Page 72-80.

Al-ghamdi et., A. (2012), "An expert system for advising postgraduate students", International Journal of Computer Science and Information Technologies, Vol. 3, No.3, Page 4529-4532.

Al Hakim, R. R., Rusdi, E., \& Setiawan, M. A. (2020), "Android based expert system application for diagnose Covid-19 disease: cases study of banyumas regency", Journal of Intelligent Computing \& Health Informatics, Vol. 1, No. 2, Page 1-13.

Alfiah, F., Adnandi, M. A., \& Rasyidin, A.F. (2019), "Expert system to identify students behavior and personality in SMK Negeri 2 Tangerang", Jurnal Techno Nusa, Vol. 16, No. 2, Page 85-92.

Ayman, M. (2011), "A prototype student advising expert system supported with an object-oriented database", International Journal of Advanced Computer Science and Applications, Vol. 1, No. 3, Page 100-105. 
Bouaiachi, Y., Khaldi, M., \& Azmani, A. (2014), "A prototype expert system for academic orientation and student major selection", International Journal of Scientific \& Engineering Research, Vol. 5, No. 11, Page 25-28.

Cavendish, W. (2013), "Identification of learning disabilities: implications of proposed DSM-5 criteria for school-based assessment", Journal of Learning Disabilities, Vol. 46, No. 1, Page 52-57.

Cheng, S. C., \& Lai, C. L. (2020), "Facilitating learning for students with special needs: a review of technology-supported special education studies", Journal of Computers in Education, Vol. 7, No. 2, Page 131-153.

Choudhury, Ridip Dev., Borbora, Khurshid Alam \& Sarma, Shikhar Kumar. (2012), Expert system based online assessment system", International Journal of Applied Information Systems, Vol. 2, No. 1, Page 30 - 33.

Choudhury, Ridip Dev., Borbora, Khurshid Alam \& Sarma, Shikhar Kumar. (2013), "ESOA: a web-based expert system for online assessment: prototype design and implementation", International Journal of Computer Science Engineering and Information Technology Research, Vol. 3, No. 2, Page 449 - 458.

Daramola, O., Emebo, O., Afolabi, I., \& Ayo, C. (2014), "Implementation of an Intelligent course advisory expert system", International Journal of Advanced Research in Artificial Intelligence, Vol. 3, No. 5, Page 6-12.

Elgaml, A. F., \& Baladoh, S. M. (2014), "An intelligent web-based system to enhance digital circuits concepts and skills for deaf students", International Journal of Engineering and Innovative Technology, Vol. 4, No. 2, Page 20 - 26.

Goodarzi, M. H., \& Rafe, V.(2012), "Educational advisor system implemented by webbased fuzzy expert systems", Journal of Software Engineering and Applications, Vol. 5, No. 07, Page 500-507.

Hallahan, D. P., \& Kauffman, J. M. (2006), Exceptional learners: introduction to special education, Pearson, London.

Hustinawaty, \& Aprianggi, R. (2014), "The development of web based expert system for diagnosing children diseases using PHP and MySQL", International Journal of Computer Trends and Technology, Vol. 10, No. 4, Page 197-202.

Ignizio, James P. (1991), "Introduction to Expert Systems : the development and implementation of rule-based exprrt systems", McGraw-Hill, inc, USA.

Lightfoot, J. M. (2014), "A web-based knowledge management tool utilizing concept maps for on-line student advising", Journal of International Technology \& Information Management, Vol. 23, No. 1, Page 41-56.

Mapunda, P. H., Omollo, A. D., \& Bali, T. A. L. (2017), "Challenges in identifying and serving students with special needs in Dodoma, Tanzania", International Journal of Child Care and Education Policy, Vol. 11, No. 1, Page 1 - 16.

Mensah, F. A., \& Badu-Shayar, J. (2016), Identification of special educational needs for early childhood inclusive education in Ghana", Journal of Education and Practice, Vol. 7, No. 11, Page 1-8. 
Muntoha, Muhammad., Akhlis, Isa \& Subali, Bambang. 2010, "Pengembangan sistem evaluasi pembelajaran berbasis web (web based learning assessment system). Prosiding Pertemuan Ilmiah XXIV, HFI Jateng \& DIY, Page 195 - 199.

Nugraha, I. C., \& Herlawati. (2016), "Sistem Pakar tes minat dan bakat jurusan kuliah berbasis android pada SMA Islam Teratai Putih Global Bekasi", Jurnal Teknik Komputer AMIK BSI, Vol. 2, No. 21, Page 138-147.

Raharjo, Trubus.;Kawuryan, Fajar.;Ahyani, L. . (2011). "Identifikasi anak leaning disability pada anak sekolah dasar", Jurnal Sosial Dan Budaya, Vol. 4, No. 2, Page 136-142.

Rapisa, D. R. (2018), "Kemampuan Guru dalam melakukan identifikasi Anak Berkebutuhan Khusus", Pedagogia, Vol. 16, No. 1, Page 16 - 24.

Rejeki, D. (2019), "Identification and assessment of the effectiveness of instruments children with special needs based Decision Support System (DSS) disorders in children with physical and motor disabilities", IJDS Indonesian Journal of Disability Studies, Vol. 6, No. 2, Page 202-209.

Russell, A. M., Bryant, L., \& House, A. (2017), "Identifying people with a learning disability: an advanced search for general practice, British Journal of General Practice, Vol. 67, No. 665, Page e842-e850.

Salekhova, L., Nurgaliev, A., Zaripova, R., \& Khakimullina, N. (2013), "The principles of designing a gamification system in teaching mathematics", Universal Journal of Educational Research, Vol. 1, No. 2, Page 42-47.

Salim, abdul., Subagya., Yusuf, Munawir \& Sari, Erma Kumala. (2015), "The Instrument development of a Decision Support System (DSS) to identifify and assess autistic syndrome", International Journal of Innovations in Engineering and Technology, Vol. 6, No. 2, Page $267-273$.

Sora, J.C. Sora, S. A. (2014), "Using appropriate e-learning systems to optimize teaching and learning", GSTF Journal on Computing (JoC), Vol. 2, No. 3, Page 47-52.

Sugiyono. (2017). Metode penelitian kuantitatif kualitatif dan R \& D. Alfabeta: Bandung.

Susanti, Ariani. (2015), "Perancangan sistem pendukung keputusan penentuan jurusan siswa SMA Negeri 2 Kutacane berbasis web dengan menggunakan metode Analytical Hierarchy Process (AHP)", Pelita Informatika Budi Darma, Vol. 9, No. 1, Page 159 - 167.

Wiliyanto, D. A. (2017a), "Analysis of teachers' understanding level, needs, and difficulties in identifying children with special needs in inclusve school in Surakarta", Journal of Education and Learning (EduLearn), Vol. 11, No. 4, Page 352.

Wiliyanto, D. A. (2017b), "The use of web based expert system application for identification and intervention of children with special needs in inclusive school", Journal of Education and Learning (EduLearn), Vol. 11, No. 4, Page 460.

Yorulmaz, Muhammet., Yavuzcan, H. Güçlü \& Togay, Abdullah. 2012, "A web-based management system and its application for student design projects", Journal of Educational and Instructional Studies in The World, Vol. 2, No. 2, Page 203 - 215. 